\title{
PENGARUH PEMBIAYAAN MUDHARABAH DAN MURABAHAH TERHADAP PROFITABILITAS (RETURN ON ASSETS) BANK PEMBIAYAAN RAKYAT SYARIAH DI INDONESIA 2012-2016
}

\author{
Yulius Dharma ${ }^{\text {a1 }}$, Ade Pristianda ${ }^{\text {a2 }}$ \\ ${ }^{a}$ Fakultas Ekonomi dan Bisnis Universitas Malikussaleh \\ 1Corresponding author: yuliusdharma@yahoo.com \\ 2 pristianda_ade@yahoo.om
}

\section{A R T I CLE I NFORMATION}

Keywords:

Mudharabah, Murabahah, Profitability (Return On Assets)

Financing.

\section{A B S T RA C T}

This study aims to determine the effect of mudharabah and murabahah financing on profitability (Return On Assets) of islamic. The story uses secondary data of Islamic banks in Indonesia from 2012 to 2016. The data analysis method used is multiple linear regression. The results show that the mudharabah financing variable has a negative and not significant effect on profitability, while the murabahah financing variable has a negative and not significant effect on profitability. Together, mudharabah and murabahah financing is not significant to profitability of Islamic banks Indonesia..

\section{PENDAHULUAN}

Berdirinya bank syariah di Indonesia memiliki dampak tersendiri baik itu untuk masyarakat maupun dalam bidang perbankan. Dalam hal ini perbankan bertugas sebagai mediasitor untuk masyarakat dimana pihak perbankan memberikan berbagai fasilitas yang ada.

Salah satu fasilitas pada bank syariah dalam bidang pembiayaan, bank syariah menyalurkan dana yang diperoleh dari masyarakat dalam bentuk simpanan dan disalurkan melalui pembiayaan. Dalam hal ini bank syariah memberikan pembiayaan kepada nasabah sehingga nasabah dapat meningkatkan ekonomi mereka, baik itu modal atau kerja sama yang di lakukan yang sebelumnya telah di setujui bersama. Akan tetapi pembiayaan yang diberikan tidak semuanya berjalan lancar, hal ini mempengaruhi tingkat profitabilitas bank syariah, apabila pembiayaan yang diberikan berjalan lancar maka profitabilitas yang dimiliki akan bagus, namun sebaliknya apabila pembiayaan yang diberikan mengalami macet hal ini akan berdampak buruk terhadap profitabilitas bank tersebut. Sehingga pihak perbankan sangat teliti dalam penyaluran pembiayaan, dimana penyaluran itu harus tepat sasaran sehingga nasabah yang menerima fasilitas pembiayaan dapat dengan lancar pada saat proses pengembalian pembiayaan yang diberikan atau tidak terjadi macet.

Profitabilitas menurut (Fadhila, 2015) adalah: "tingkat kemampuan perusahaan menghasilkan laba, yang mana profitabilitas merupakan laba sebelum pajak dengan total asset yang dimiliki pada bank periode tertentu, dimana rasio profitabilitas ialah perbandingan laba yang dimiliki perusahaan dengan ekuitas yang digunakan". Dari uraian di atas penulis ingin meneliti pengaruh pembiayaan mudharabah dan murabahah terhadap profitabilitas (Return On Assets) Bank Pembiayaan Rakyat Syariah.

Berdasarkan latar belakang diatas maka menjadi tujuan penelitian yaitu :

1. Untuk mencari cara mengetahui pengaruh pembiayaan mudharabah terhadap profitabilitas Bank Pembiayaan Rakyat Syariah (Return On Assets)di Indonesia. 
2. Untuk cara mengetahui pengaruh pembiayaan murabahah profitabilitas Bank Pembiayaan Rakyat Syariah (Return On Assets) di Indonesia.

3. mengetahui pengaruh pembiayaan mudharabah dan murabahah terhadap Pembiayaan Rakyat Syariah (Return On Assets) di Indonesia.

\section{TINJAUAN TEORITIS}

\section{Pengertian Bank Umum}

Menurut Undang-undang No. 10 tahun 1998, mendefinisikan Bank sebagai badan usaha yang menghimpun dana dari masyarakat dalam bentuk simpanan dan menyalurkannya kepada masyarakat, dalam bentuk kredit atau dalam bentuk lainnya dalam rangka meningkatkan taraf hidup rakyat banyak. Bank sendiri terbagi menjadi dua, yaitu Bank Umum dan Bank Perkreditan Rakyat. Dalam menjalankan usahanya dibagi menjadi dua klasifikasi, yaitu bank konvensional dan bank syariah.

\section{Pengertian Bank Syariah}

Menurut UU No. 21 tahun 2008 tentang Perbankan Syariah, bahwa Perbankan Syariah adalah segala sesuatu yang menyangkut tentang Bank Syariah dan Unit Usaha Syariah, mencakup kelembagaan, kegiatan usaha, serta cara dan proses dalam melaksanakan kegiatan usahanya.

\section{Bank Perkreditan Rakyat Syariah}

Menurut UU No. 7 tahun 1992 tentang Perbankan, Bank Perkreditan Rakyat adalah bank yang melaksanakan kegiatan secara konvensional atau berdasarkan prinsip syariah yang dalam kegiatannya tidak memberikan jasa dalam

lalu lintas pembayaran.

\section{Pengertian Pembiayaan Mudharabah}

Pengertian pembiayaan mudharabah menurut (Inti Dwi Permata et al., 2014), sebagai berikut: "al-mudharabah adalah akad kerja sama usaha antara dua pihak dimana pihak pertama (shahibul maal) menyediakan seluruh (100\%) modal, sedangkan pihak lainnya menjadi pengelola. Keuntungan usaha secara mudharabah dibagi menurut kesepakatan yang dituangkan dalam kontrak, sedangkan apabila rugi ditanggung oleh pemilik modal selama kerugian itu bukan akibat kelalaian si pengelola.

\section{Pengertian Ba'i al-Murabahah}

Pengertian pembiayaan murabahah menurut (Fadhila, 2015), sebagai berikut: "adalah jual beli barang pada harga asal dengan tambahan keuntungan yang disepakati. Dalam al-murabahah, penjual harus memberi tahu harga produk yang ia beli dan menentukan suatu tingkat keuntungan sebagai tambahannya.

\section{Penelitian Sebelumnya}

Menurut (Wahyuni, 2016), analisis pengaruh pembiayaan mudharabah dan musyarakah terhadap tingkat profitabilitas (Return On Equity) (studi pada bank yang terdaftar di Indonesia "dalam penghimpunan dana pihak bank akan mengalokasikan dana untuk kegiatan yang menghasilkan keuntungan. Salah satunya adalah pembiayaan mudharabah dan musyarakah. Kedua pembiayaan tersebut akan menghasilkan laba dari perhitungan bagi hasil. Dari keuntungan tersebut akan dibagi antara pihak bank dan nasabah. Keuntungan tersebut akan digunakan untuk mengembalikan modal yang dialokasikan untuk pembiayaan. Sehingga dari tingkat pengembalian modal tersebut dapat mengukur tingkat profitabilitas bank dengan membandingkan keuntungan atau laba dan modal yang dimilikinya".

Jenis penelitian ini yaitu penelitian deskriptif dengan pendekatan kuantitatif. Variabel yang dipakai yaitu variabel bebas sebagai pembiayaan mudharabah dan musyarakah, variabel terikatnya yaitu, ROE. Data yang digunakan adalah data sekunder dengan sumber dari website Bank Indonesia teknik pengambilan sampel menggunakan teknik purposive sampling. Teknik pengumpulan data menggunakan teknik dokumentasi berupa data laporan tahunan. Teknik analisis data yang digunakan adalah analisis regresi berganda dan uji asumsi klasik (uji normalitas, heterokedastisitas, multikolinieritas, autokorelasi), serta uji siqnifikansi (uji t, uji f, koefisien deterrminasi). 


\section{METODE PENELITIAN}

\section{Objek Dan Lokasi Penelitian}

Dalam penelitian ini yang menjadi lokasi penelitian adalah Bank Pembiayaan Rakyat Syariah yang ada di Indonesia. Pembiayaan mudharabah dan murabahah adalah sebagai variabel bebas (independen) sedangkan Bank Pembiayaan Rakyat Syariah sebagai variabel terikat (dependen). Data yang digunakan yaitu dari tahun 2012 sampai dengan 2016. Sumber, data otoritas jasa keuangan (ojk), 2017. Di atas adalah data komposisi pembiayaan bank BPRS.

\section{Jenis Dan Sumber Data}

Penelitian ini menggunakan data sekunder yang merupakan data runtut waktu (time series). Adapun data yang digunakan yaitu dari Perbankan Syariah, Otoritas Jasa Keuangan (OJK) dari tahun 2012 sampai dengan 2016.

\section{Uji Asumsi Klasik}

\section{Uji Normalitas}

Uji normalitas adalah untuk mengetahui apakah residual terdistribusi secara normal atau tidak. Pengujian normalitas dapat dilakukan dengan menggunakan metode Jarque-Bera (J-B) (Widarjono, 2013).

Jika nilai probability dari statistic J-B lebih besar dari taraf kepercayaan $5 \%(0,05)$ berarti bahwa residual data berdistribusi normal. Sebaliknya jika nilai probability dari statistik J-B lebih kecil dari taraf kepercayaan 5\% $(0,05)$ berarti bahwa residual data tidak berdistribusi normal (widarjono, 2009).

\section{Uji Multikolinearitas}

Menurut Gujarati (2004), multikolinearitas adalah hubungan linear yang terjadi diantara variabel-variabel independen. Pengujian terhadap gejala multikolinearitas dapat dilakukan dengan menghitung Variance Inflation Factor (VIF) dari hasil estimasi. Jika VIF < 10 maka antara variable independen tidak terjadi hubungan yang linear (tidak ada multikolinearitas).

Multikolinearitas dalam penelitian ini diuji dengan melihat nilai tolerance dan variance inflation factor (VIF). Apabila nilai VIF lebih kecil dari 10 maka diduga tidak ada multikolinearitas. Begitu pula nilai tolerance yang mendekati satu maka bias disimpulkan juga tidak ada masalah multikolinearitas (widarjono, 2013).

\begin{tabular}{|l|l|l|}
\hline \multirow{2}{*}{ Akad } & 2012 & 2016 \\
\cline { 2 - 3 } & Desember & Desember \\
\hline Mudharab & 99 & 156.256 \\
Murabaha & 2.854 & 5.053 .76 \\
& & \\
\hline
\end{tabular}

\section{Uji Heteroskedastisitas}

Uji Heteroskedastisitas bertujuan menguji apakah dalam model regresi terjadi ketidaksamaan variance dari residual satu pengamatan ke pengamatan yang lain (Ghozali, 2007). Apabila asumsi tersebut tidak terpenuhi maka akan terjadi masalah heteroskedastisitas yaitu suatu keadaan dimana varians dari kesalahan penganggu tidak sama untuk semua nilai variable bebas Metode pengujian yang lain dapat digunakan adalah metode white dimana hipotesis Heteroskedastisitas yang dipakai:

- Ho:tidakada heteroskedast $(>0,05)$

- $\quad$ Ha: ada heteroskedastisitas $(0,05)$

Dasar pengambilan keputusan, jika nilai probabilitas dari Obs*R-Squared

$<0,05$, maka Ho ditolak; jika nilai probabilitas dari Obs*R-Squared < 0,05, maka Ho diterima (Yusuf, 2014).

\section{HASIL PENELITIAN DAN PEMBAHASAN}

\section{Gambaran Umum Bank Pembiayaan Rakyat Syariah}

Bank Perkreditan Rakyat (BPR) sudah ada di Indonesia pada abad ke 19. Pada masa pemerintahan Belanda, BPR pada masa itu dikenal oleh masyarakat dengan istilah Lumbung desa, Bank Desa, Bank Tani, dan Bank Dagang Desa yang terdapat pada masa itu yaitu hanya di Bali dan Jawa. Pada tahun 1929 didirikan badan yang bertugas menangani kredit dipedesaan yaitu, Badan Kredit Desa (BKD) yang berdiri pada saat itu di daerah Jawa dan Bali, untuk pengawasan dan pembinaan, pemerintah Kolonial Belanda membentuk kas pusat dan dinas Perkreditan Rakyat, dengan nama lembaga Instansi Kas Pusat (IKP). 


\section{Pembahasan}

Berdasarkan hasil pengujian asumsi klasik yang telah dilakukan sebelumnya, dapat diketahui bahwa uji normalitas, multikolinearitas, dan heteroskedastisitas pada data yang sudah diuji terbebas dari berbagai gejala asumsi klasik atau memiliki estimator yang baik.

Dari analisis data dapat disimpulkan bahwa mudharabah berpengaruh negatif dan tidak signifikan terhadap Profitabilitas (Return On Asset) Bank Pembiayaan Rakyat Syariah di Indonesia. Artinya banyak sedikit pembiayaan yang disalurkan dengan akad mudharabah ke masyarakat, tidak akan mempengaruhiReturn On Asset Bank Pembiayaan Rakyat Syariah di Indonesia. Pembiayaan mudharabah adalah pembiayaan bagi hasil dengan tingkat nisbah berbeda antara bank syariah dan nasabah bank syariah. Dalam hal ini belum memberikan kontribusi yang cukup signifikan terhadap laba bank dari margin yang diperoleh setiap pembiayaan yang disalurkan. Hal ini menyebabkan pembiayaan mudharabah tidak berpengaruh terhadapReturn On Asset. Dan murabahah berpengaruh negatif dan tidak signifikan terhadap Profitabilitas (Return On Asset) Bank Pembiayaan Rakyat Syariah di Indonesia. Artinya banyak sedikit pembiayaan yang disalurkan dengan akad murabahah ke masyarakat, tidak akan mempengaruhi Return On Asset Bank Pembiayaan Rakyat Syariah di Indonesia. Pembiayaan murabahah merupakan produk perbankan syariah dengan prinsip jual-beli belum memberikan kontribusi yang cukup signifikan terhadap laba bank dari margin yang diperoleh dari setiap pembiayaan yang disalurkan. Hal ini menyebabkan produk pembiayaan murabahah tidak berpengaruh terhadap Return On Asset.

Variabel pembiayaan mudharabah (X1) berpengaruh negatif dan tidak signifikan terhadap profitabilitas (Y), sedangkan variabel pembiayaan murabahah (X2) berpengaruh negatif dan tidak signifikan terhadap profitabilitas (Y). Secara bersama-sama pembiayaan mudharabah dan murabahah tidak signifikan terhadap Profitabilitas (Return On Asset) Bank Pembiayaan Rakyat Syariah (Return On Assets) Di Indonesia. Dan kemampuan model ini dalam menjelaskan pengaruh perubahan variabel pembiayaan mudharabah dan murabahah terhadap profitabilitas sebesar $35,8498 \%$ sedangkan jumlah yang tersisa 64,1502 $\%(0,641502)$ dipengaruhi oleh perubahan variabel lain diluar model.

\section{KESIMPULAN DAN SARAN \\ Kesimpulan}

Mudharabah berpengaruh negatif dan tidak signifikan terhadap Profitabilitas (Return On Asset) Bank Pembiayaan Rakyat Syariah di Indonesia. Dan murabahah berpengaruh negatif dan tidak signifikan terhadap Profitabilitas (Return On Asset) Bank Pembiayaan Rakyat Syariah di Indonesia

Bersama-sama pembiayaan mudharabah dan murabahah tidak signifikan terhadap Profitabilitas (Return On Asset) Bank Pembiayaan Rakyat Syariah (Return On Assets) Di Indonesia. Dan kemampuan model ini dalam menjelaskan pengaruh perubahan variabel pembiayaan mudharabah dan murabahah terhadap profitabilitas sebesar 35,8498\% sedangkan jumlah yang tersisa $64,1502 \%(0,641502)$ dipengaruhi oleh perubahan variabel lain diluar model.

\section{Saran}

Berdasarkan kesimpulan yang telah dikemukakan diatas, maka yang menjadi saran dalam penelitian ini adalah melakukan sosialisasi mengenai perbankan masyarakat lebih bijak dalam produk pembiayaan. Dalam hal ini diharapkan pihak perbankan lebih tepat dalam hal penyaluran pembiayaan sehingga berimbas kepada Profitabilitas bank. Diharapkan Penelitian selanjutnya dapat menambah variabel untuk memperkuat teori dari penelitian penulis.

\section{DAFTAR PUSTAKA}

Amalia, N. (2016). Struktur Pembiayaan Dan Pengaruhnya Terhadap Profitabilitas Bank Muamalat Indonesia Dan Bank Syariah Mandiri. Jurnal Ilmu Dan Riset Akuntansi, 5(5), 1-16. Retrieved from https://ejournal.stiesia.ac.id/jira/article/view/1 704

Aziz, L. H., Syariah, K. P., Syariah, F., Hukum, D. 
A. N., \& Hidayatullah, U. I. N. S. (2010).

Pengaruh Financing To Deposit Ratio ,

Pendapatan Bagi Hasil Dan Total Asset

Terhadap Profitabilitas.

Departemen Pengembangan Pengawasan dan

Manajemen Krisis Otoritas Jasa Keuangan.

(2015). Laporan Profil Industri Perbankan

(LPIP) Triwulan III 2015, 3-159.

Ekonomika, F., Bisnis, D. A. N., \& Diponegoro, U. (2014). MEMPENGARUHI

PEMBIAYAAN MURABAHAH BA' I

BITSAMAN AJIL ( Studi Kasus: BMT

Bina Umat Mandiri di Kota Tegal ).

Amalia, N. (2016). Struktur Pembiayaan Dan Pengaruhnya Terhadap Profitabilitas Bank Muamalat Indonesia Dan Bank Syariah Mandiri. Jurnal Ilmu Dan Riset Akuntansi, 5(5), 1-16. Retrieved from https://ejournal.stiesia.ac.id/jira/article/view/17 04

Aziz, L. H., Syariah, K. P., Syariah, F., Hukum, D. A. N., \& Hidayatullah, U. I. N. S. (2010). Pengaruh Financing To Deposit Ratio , Pendapatan Bagi Hasil Dan Total Asset Terhadap Profitabilitas.

Departemen Pengembangan Pengawasan dan Manajemen Krisis Otoritas Jasa Keuangan. (2015). Laporan Profil Industri Perbankan (LPIP) Triwulan III 2015, 3-159.

Ekonomika, F., Bisnis, D. A. N., \& Diponegoro, U. (2014). MEMPENGARUHI PEMBIAYAAN MURABAHAH BA' I BITSAMAN AJIL ( Studi Kasus: BMT Bina Umat Mandiri di Kota Tegal ).

Fadhila, N. (2015). Analisis Pembiayaan Mudharabah Dan Murabahah Terhadap Laba Bank Syariah Mandiri. Riset Akuntansi Dan Bisnis, 15(1), 52-64.

Ghozali, (2007). Uji Asumsi Klasik. 4-10.

Gujarati, (2004). teori multikolinearita. 2-8.

Hismendi. (2016). Analisis pengaruh tenaga kerja terhadap nilai produksi pada industri kecil di kota banda aceh, 1-13.

Wahyuni, M. (2016). Pengaruh Volume Pembiayaan Bagi Hasil dan Pembiayaan Murabahah terhadap Kinerja Keuangan Bank Umum Syariah dengan NPF sebagai Variabel Moderasi Effect of Profit Sharing Financing and Murabahah Financing to Islamic Bank Performance with NPF as Moderation V. Ebbank, Vol. 7(1), 1-10.

Widarjono, (2009). teori uji asumsi klasik. 3-10. winarno, (2007). teori uji asumsi klasik. 2-10. yusuf, (2014). teori uji heterokedastisitas. 4-10 